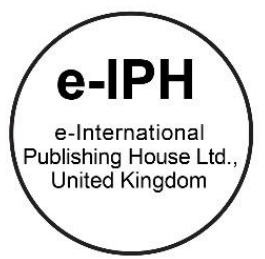

\title{
Facilities Management AUDIT in Managing Healing Facilities in Public Health Care Built Environment: User Satisfaction Viewpoint
}

\author{
Ahmad Ezanee Hashim ${ }^{1 *}$, Siti Aida Samikon ${ }^{2}$, Mohamad Sufian Hasim ${ }^{3}$, Mahyudin Mahmood 4 \\ 1,3,4 Faculty of Architecture, Planning, and Surveying, Universiti Teknologi MARA (UiTM), 40450 Shah Alam, Selangor, Malaysia. \\ ${ }^{2}$ Faculty of Science, Technology, Engineering and Mathematics, International University of Malaya-Wales (IUMW), 50480 Kuala Lumpur, \\ Malaysia
}

\begin{abstract}
Healthcare organizations have recognized the powerful impact of supply breakdowns and have exploited supply chain management for their quality program, especially regarding lean operations. This study aims to investigate strategic Facilities Management (FM) as a function to support the objectives of providing efficient services to healthcare sector through measuring user satisfaction focusing on public training hospital building. This research involved correlation analysis. The findings show that there is a strong significant relationship among the building performance criteria and the importance of POE guidelines in functional and technical performance criteria.

(c) 2016. The Authors. Published for AMER ABRA by e-International Publishing House, Ltd., UK. This is an open access article under the CC BYNC-ND license (http://creativecommons.org/licenses/by-nc-nd/4.0/).

Peer-review under responsibility of AMER (Association of Malaysian Environment-Behaviour Researchers), ABRA (Association of Behavioural Researchers on Asians) and cE-Bs (Centre for Environment-Behaviour Studies), Faculty of Architecture, Planning \& Surveying, Universiti Teknologi MARA, Malaysia.
\end{abstract}

Keywords: Sustainable; Quality of Life; Facilities Management Audit; Public Healthcare; Built Environment

\section{Introduction}

Healthcare organizations have recognized the powerful impact of supply breakdowns and have exploited supply chain management for their quality program, especially regarding lean operations. There are many contributors to poor working environments in the healthcare sector. Some studies relate to inadequate equipment, such as patient lifts and facilities for safe disposal of syringes, needles, and medical waste. However, one area that has so far largely been overlooked relates to the built environment. This study aims to investigate strategic Facilities

\footnotetext{
* Corresponding author. Tel.: +60011-35447108

E-mail address: ezanee54@gmail.com
}

2398-4287 @ 2016. The Authors. Published for AMER ABRA by e-International Publishing House, Ltd., UK. This is an open access article under the CC BY-NC-ND license (http://creativecommons.org/licenses/by-nc-nd/4.0/).

Peer-review under responsibility of AMER (Association of Malaysian Environment-Behaviour Researchers), ABRA (Association of Behavioural Researchers on Asians) and CE-Bs (Centre for Environment-Behaviour Studies), Faculty of Architecture, Planning \& Surveying, Universiti Teknologi MARA, Malaysia.

DOI: http://dx.doi.org/10.21834/e-bpj.v1i4.376 
Management (FM) as a function to support the objectives of providing efficient services to healthcare sector through measuring user satisfaction.

Facility management covers a vast scope of real estate management, financial management, change management, human resources management, health and safety, contract management, building and engineering services maintenance, and domestic services (Atkin and Brooks, 2009). Effective facility management is vital to the success of an organization by contributing to the achievement of its strategic and operational objectives (Chanter and Swallow, 2007). Shohet and Lavy (2004) recognized that a successful FM is "highly dependent on cost effectiveness and performance management." Facility management professionals work in a complex environment in which they have to keep up with a significant amount of information provided by various domains. Facilities management is a balance between technical, managerial and business acumen that may be related to operational, tactical and strategic decision-making processes (Kamaruzaman \& Ahmad Zawawi, 2010) and the management of multi-disciplinary activities to ensure continuous functionality of the built environment by linking an integrating people, place, processes and technology (Mohd Noor \& Pitt, 2010). One of the complex types of facilities in which facility managers was faced with massive amounts of information on a daily or even hourly basis and require critical decisions is healthcare facility management. Healthcare facilities include hospitals, clinics, dental offices, out-patient surgery centers, birthing centers, and nursing homes (OSHA, 2012). Hospitals are 24-hour working facilities that employ a wide variety of trades, from medical staff to mechanical maintenance, medical equipment maintenance, housekeeping, food service, building and grounds maintenance, laundry, and administrative staff (OSHA, 2012).

\section{Background of Teaching Hospital}

Hospitals need to reliant on gained information regarding user's satisfactions to assist in the diagnosis, management, and education for better and improved services and practice, thus can allow the building management and health ministry to identify the weakness of healthcare services provided and improve it. Despite the growth in undergraduate medical education over the last decade, causing the expansion of a new kind of hospital used for teaching where large state or public district hospitals affiliated with both public and private medical schools for teaching purposes in addition to service provision and research for the affiliated university staffs. However, in this case, previously service oriented hospitals are made to function as a teaching hospital, allowing public hospitals to be used for teaching undergraduate medicine. A training hospital is a hospital that provides clinical education and training to future and current doctors, nurses, and other health professionals, in addition to delivering medical care to patients. They are affiliated with medical schools or universities (hence the alternative term is university hospital), and may be owned by a university or may form part of a wider regional or national health system. Some teaching hospitals also have a commitment to research and are centers for experimental, innovative and technically sophisticated services. For these multitudes of functions, a teaching hospital must be owned by a medical school or a university but regarding clinical service provision, it may be part of a national health system (Fauzi, 2012).

In Malaysia, there are only three teaching hospitals under a medical faculty or university. The fourth is schedule to start operation in late 2016. There are University Malaya Medical Centre (UMMC), University Kebangsaan Malaysia Medical Centre (UKM), and Hospital University Sains Malaysia (USM). These teaching hospitals are under the purview of the Ministry of Higher Education. According to Fauzi (2012), Malaysia needs more hospitals, and the way forward is to build more teaching hospitals. International Islamic University Malaysia (IIUM) teaching hospital project is a step in the right direction which that will lead to an improvement in the healthcare delivery in the country.

Figure 1 and figure 2 shows general teaching hospital relationships and its primary clinical relationships by Carr (2011). The diagrams show the movement and communication of people, materials, and waste. The physical configuration of a hospital, its transportation, and logistics systems are inextricably intertwined. In a large hospital complex, a typical nursing unit is a principal element of the overall configuration. Nursing units today tend to be more compact shapes compared to the past in an attempt to shorten the distance between the nurse station and the patient's bed. 


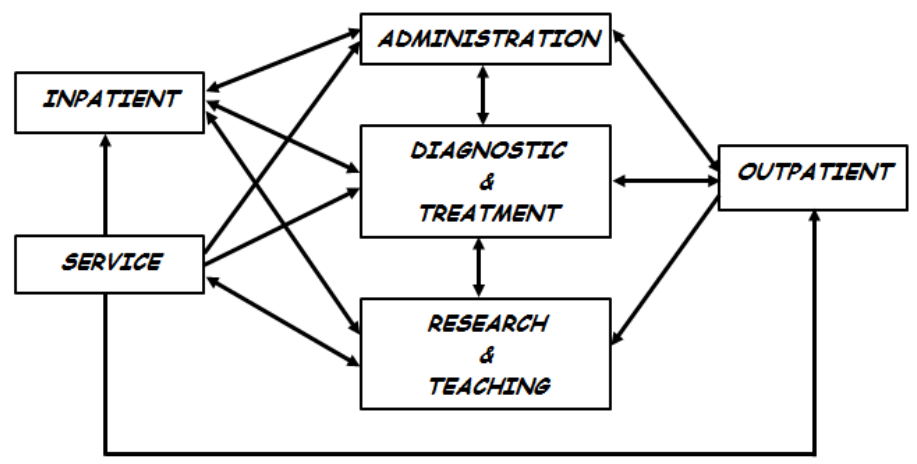

Figure 1 : General Hospital Relationship, (Carr, 2011)

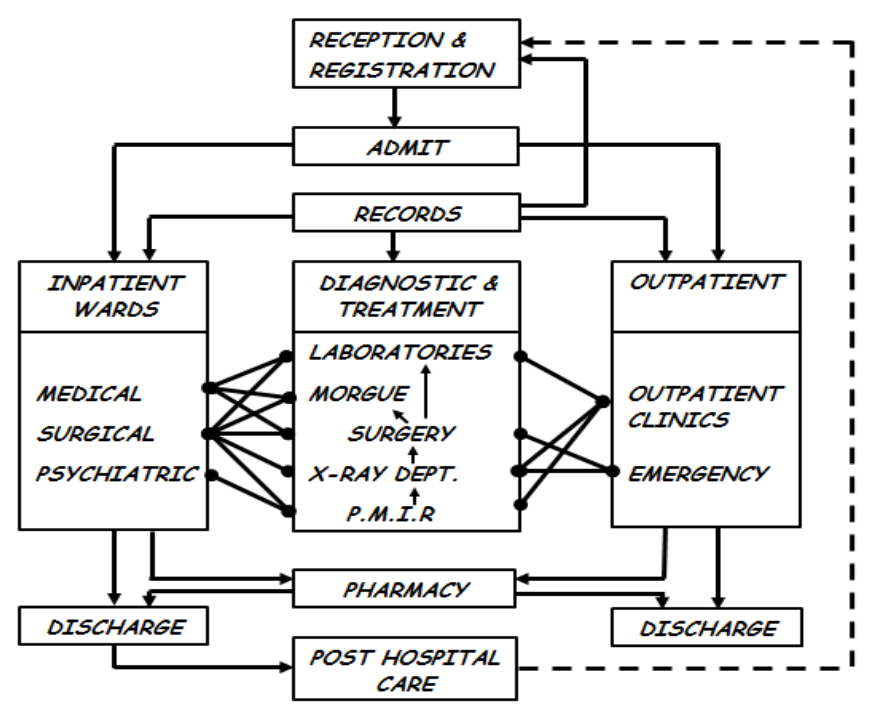

Figure 2: Major Clinical Relationship, (Carr, 2011)

\section{User Satisfaction}

Customers are anyone who expects to receive the maximum benefit of a service and complying their satisfaction in the health sector is a very complex process. They are in more than one tier, and there are medical and administration staffs, patients and visitors, government as a funding party, and society in general. Each of these requiring the facility's support in different degrees based on their different values, beliefs, perceptions and expectations (Payne, 2000). However, understanding of customer perceptions is essential to remain competitive in today's market. The organisation must not only know the level of customer satisfaction with its current product or service but also know the degree of customer satisfaction with its competitors' (Gonza'lez et al., 2005). To ensure satisfaction of various customer needs, it is essential that facilities management identifies focuses and monitors key performance indicators and it is highly subjective. Therefore, it is important for the organization to interact with its customers if it wishes to improve its services (Barrett and Baldry, 2003) and improve the image of the organisation 
(Lewis, 2000). They need to constitute the rational framework for the distribution of human and other resources between and within health care facilities (Kontodimopoulos et al. 2006). The variables that affect patients and nonpatients /customers satisfaction were categorized into three main groups; (i) room features (ii) services by the facilities management and (iii) the environment. According to Kursunluoglu (2011), another stronger tool of customer satisfaction is service quality. Lepkova \& Zokaite-Jefimovient (2012), supported these by designed the dependence between the quality of service, customer satisfaction, and profitability is interrelated as shown in Figure 3.

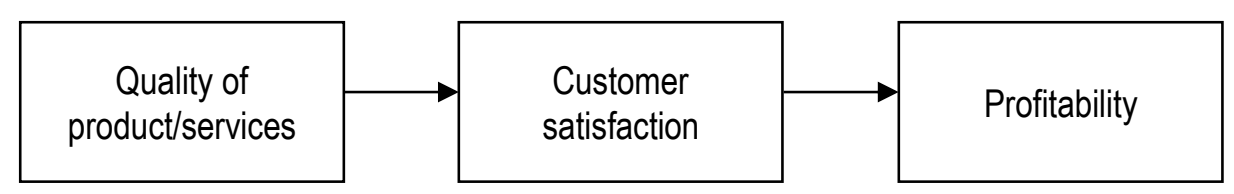

Figure 3: Dependence between Quality, Satisfaction, and Profitability Sources: Quoted by (Lepkova \& Žūkaitè-Jefimovienè, 2012) from (Fečikova, 2004)

The building's function is to provide shelter and space for activities that carried out by the building occupants. The facilities in the building must perform and appropriate to its use. The needs of occupants are affected by the building performance and occupant's evaluation of the buildings. Post Occupancy Evaluation (POE) is a method to empower the occupant's opinion as the benchmark of building performance evaluation. POE comprises as one of the techniques that are used to evaluate whether a building meets the user's requirement (Natasha 2008). Wauters (2005) confirms the value of "user satisfaction surveys" as a herald to service-level benchmarking and successive recommendations for improving facilities services. Used as a feed forward process, POE can support evidencebased design throughout the planning and implementation of new and existing facilities (Friesen, Trojan et al. 2008). Thus, the objective of this research is to analyse the level of satisfaction of user's need in functional and technical performance aspect of POE. Secondly, to propose a guideline on building performance framework based on user' satisfaction evaluation done for public teaching hospitals building. Hafizi et. al (2010), based on Lewis (200), suggested facilities management is responsible for safety and wellness of building operation and maintenance of facilities at the managed building. Poor work quality and insufficient work programme for maintaining and managing the facilities may lead to the accident, injury and death (Hafizi, 2010). Previous study on health care building assessment through post-occupancy audit, Hashim et.al (2015) highlighted that comprehensive documentation in the context of knowledge during planning and implementation, design expectations and how decisions are being made can be used by the design consultant and hospital managers as a reference data to improve the specific services area for future design.

\section{Methodology}

The methodology consisted of a questionnaire survey, semi-structured interview, and a case study on selected public hospitals in Selangor, Malaysia. The case study samples were located in highly dense urban area in Selangor, Malaysia. The research question were tested through a semi-structured interview with the expert officer related to managing the operational in government's training hospital building, and preliminary questionnaire survey to training students, clinical and administrative staffs in Selangor district. Through literature reviews, variables have been identified, and key variables have been selected of the closed- ended questionnaire and interview. An extensive literature review questionnaire survey was prepared based on the primary objective to review and analyse the performance level of the training hospital, the standard of satisfaction of users' needs on technical and functional building performance, and implementation of the strategy for the betterment of practice in training hospital building. The case studies selected were teaching hospital in Selangor districts. Questionnaires distributed to three locations 
which are University Kebangsaan Malaysia Medical Centre (UKMMC), University Malaya Medical Centre (UMMC) and Hospital Sungai Buloh. The respondents' samples are limited to administrative staffs, training students, and clinical staffs. The questionnaires data were analysed using frequency analysis through Likert scale approach and descriptive analysis through mean score analysis. The data from questionnaires are processed by using Statistical Package for Social Science (SPSS) computer software to ease frequency analysis purposes.

\section{Data Collection}

The data collection process involved primary and secondary data. The primary data was collected by questionnaires which aim at health sector by identifying the management and critical success factor of facilities manager in a public hospital in Selangor. The selection of public hospital is based on numbers of bed and in operation for ten years and above. The hospitals are Pusat Perubatan Universiti Malaya (PPUM), Pusat Perubatan Universiti Malaya (PPUKM), and Hospital Sungai Buloh (HSP). In-depth assessment and face to face interview with hospital management, and consultant of services provider were conducted. Inputs from hospital management were required to evaluate their management practice, issues and problems faced and to obtain the critical success factor of facilities manager required. The semi-structured interviews were conducted with the aids of survey questionnaire form, supported by visual photographs and illustration after each interview. On-site assessment or site visits are a necessary and essential part for verifying the information obtains a review to the actual condition of a teaching hospital. All of the data collected was schedule and analyses. The analysis begins by reviewing the public hospital case study, informing the reader of the location, no of beds and facilities provided. The data collected was analyzed using statistical technique comprised of frequencies and percentages as well as graphical methods.

\section{Result Analysis and Findings}

Discussion on the results will cover the summary of correlation analysis between building performance criteria and the importance of POE guideline. It is divided into two categories which for technical and functional performance criteria. The finding outcome is used to allocate and identify the proposed framework guidelines for the public teaching hospital building.

Table 1: Correlation Analysis between Building Performance Criteria and Importance of POE Guideline (Technical Performance Criteria)

\begin{tabular}{|c|c|c|c|c|c|}
\hline \multirow[t]{3}{*}{ No } & \multicolumn{3}{|c|}{ Correlation Coefficient } & Average & Region \\
\hline & \multicolumn{3}{|c|}{$\begin{array}{l}\text { "Excellent" if } 0.80<\text { Correlation } \\
\text { Coefficients } \leq 1.00 \\
\text { "Very Good" if } 0.65<\text { Correlation } \\
\text { Coefficients }<0.80 \\
\text { " if } 0.50<\text { Correlation Coefficients }<0.65 \\
\text { " if } 0.00 \leq \text { Correlation Coefficients }<0.50\end{array}$} & & \\
\hline & UMMC & $\begin{array}{l}\text { Hospital } \\
\text { Sg.Buloh }\end{array}$ & UKMMC & & \\
\hline Health & 0.375 & 0.837 & 0.693 & 0.64 & High Correlation \\
\hline Safety & 0.518 & 0.861 & 0.790 & 0.72 & High Correlation \\
\hline Security & 0.432 & 0.861 & 0.899 & 0.73 & High Correlation \\
\hline Efficiency & 0.435 & 0.744 & 0.851 & 0.68 & High Correlation \\
\hline Durability & 0.282 & 0.595 & 0.570 & 0.48 & Low Correlation \\
\hline Adaptability & 0.277 & 0.585 & 0.561 & 0.47 & Low Correlation \\
\hline
\end{tabular}




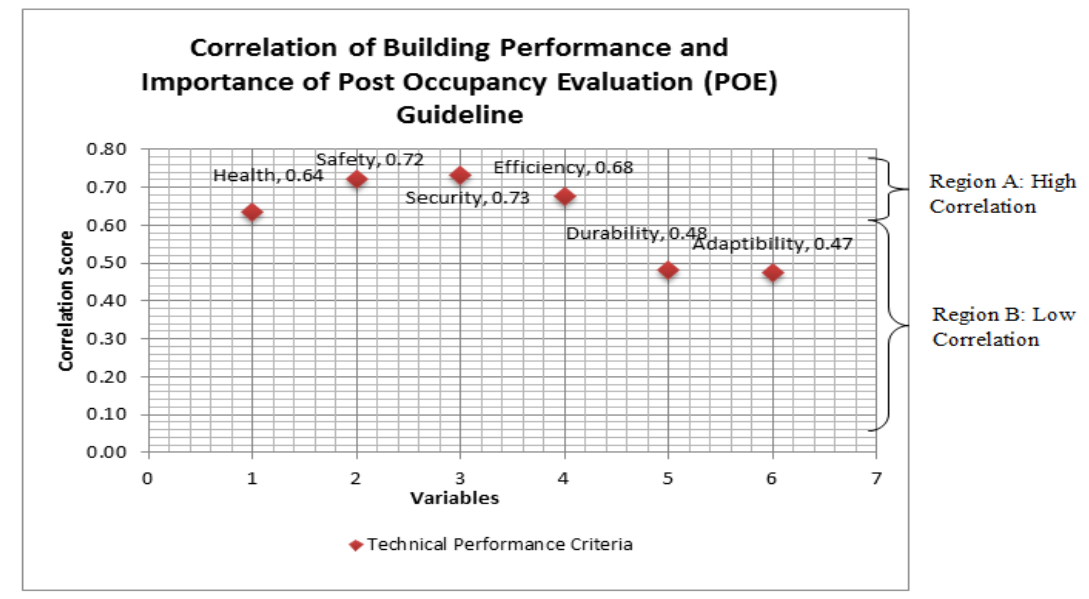

Figure 2: Correlation Analysis between Building Performance Criteria and Importance of POE Guideline (Technical Performance Criteria)

\section{Technical Performance Criteria}

Table 1 shows the correlation analysis between Building Performance Criteria and Importance of POE Guideline. The majority of the correlation coefficient for building performance criteria in areas of technical performance have high correlation and low correlation with the correlation score for the importance of POE guideline. Thus, this finding can be used and considered in selecting as criteria allocated in proposed guidelines which are relevant in evaluating the performance of public teaching hospital buildings in Malaysia. Figure 3 below are the findings that depicted from the Table 1.

\section{a) Region A - High correlations}

The correlation coefficient between technical building performance and the importance of POE Guideline are positively high based on security, safety, and efficiency and health criteria. The high correlation coefficients indicate that level of importance of technical building performance criteria based on the POE has a strong positive relationship with the need of POE framework guideline in a public teaching hospital.

b) Region B - Low correlations

The correlation coefficient between technical building performance and the importance of POE Guideline are low based on durability and adaptability criteria. The low correlation coefficients show that level of importance of technical building performance criteria based on the POE has a low relationship with the need of POE framework guideline in a public teaching hospital. Despite having low correlation, it does not constitute negative correlation. This indicates the low correlation is the difference in perception between the building occupants' perception which is influenced by their background, working experience, knowledge, and technical skills.

\section{Functional Performance Criteria}

Table 2 below illustrates the correlation between functional building performance criteria and the importance of POE guideline. 
Table 2: Correlation Analysis between Building Performance Criteria and Importance of POE Guideline (Functional Performance Criteria).

\begin{tabular}{|c|c|c|c|c|c|}
\hline \multirow[t]{3}{*}{ No } & \multicolumn{3}{|c|}{ Correlation Coefficient } & Average & Region \\
\hline & \multicolumn{3}{|c|}{$\begin{array}{c}\text { "Excellent" if } 0.80<\text { Correlation } \\
\text { Coefficients } \leq 1.00 \\
\text { "Very Good" if } 0.65<\text { Correlation } \\
\text { Coefficients }<0.80 \\
\text { "Good" if } 0.50<\text { Correlation } \\
\text { Coefficients }<0.65 \\
\text { "Poor" if } 0.00 \leq \text { Correlation } \\
\text { Coefficients }<0.50\end{array}$} & & \\
\hline & UMMC & $\begin{array}{l}\text { Hospital } \\
\text { Sg.Buloh }\end{array}$ & UKMMC & & \\
\hline Functionality & 0.146 & 0.617 & 0.445 & 0.40 & Low Correlation \\
\hline Social & 0.166 & 0.347 & 0.203 & 0.24 & Low Correlation \\
\hline Psychology & 0.365 & 0.492 & 0.581 & 0.48 & Low Correlation \\
\hline Aesthetics & 0.163 & 0.160 & 0.158 & 0.16 & Low Correlation \\
\hline O\&M & 0.415 & 0.351 & 0.540 & 0.44 & Low Correlation \\
\hline Comfort & 0.553 & 0.434 & 0.694 & 0.56 & $\begin{array}{c}\text { High } \\
\text { Correlation }\end{array}$ \\
\hline Circulation & 0.284 & 0.413 & 0.591 & 0.43 & Low Correlation \\
\hline Culture & 0.179 & 0.403 & 0.491 & 0.36 & Low Correlation \\
\hline Serviceability & 0.425 & 0.552 & 0.678 & 0.55 & $\begin{array}{c}\text { High } \\
\text { Correlation }\end{array}$ \\
\hline
\end{tabular}

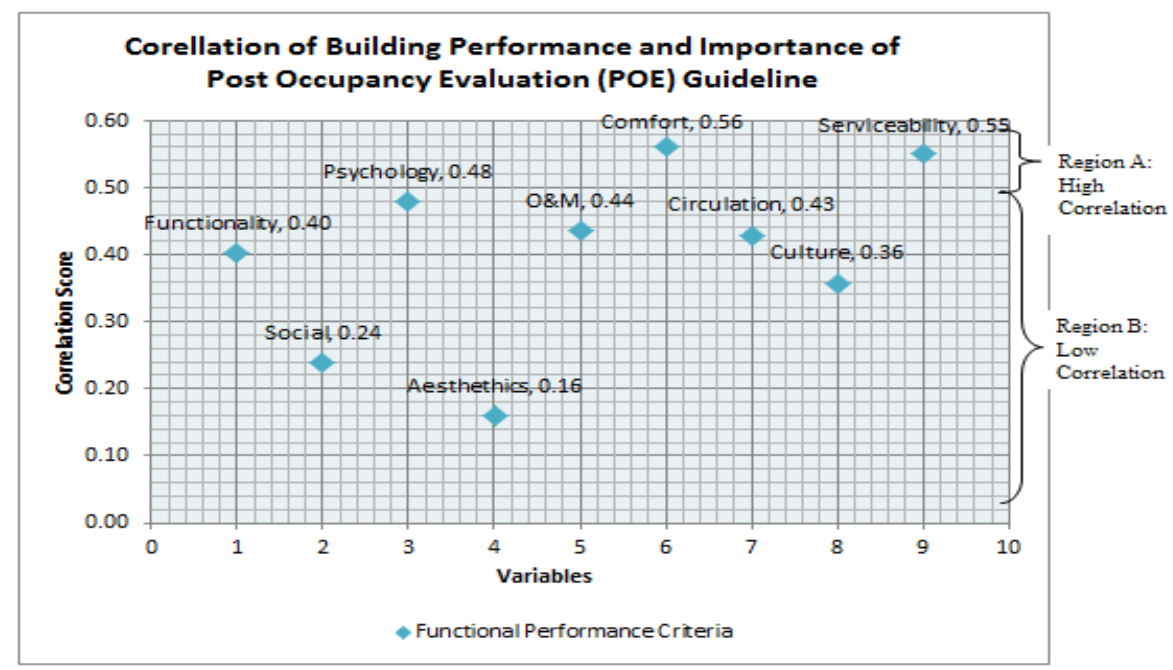

Figure 3: Correlation Analysis between Building Performance Criteria and Importance of POE Guideline (Functional Performance Criteria)

Below are the findings that can be depicted from the Table 2:

a) Region A - High correlations

The correlation coefficient between functional building performance and the importance of POE Guideline are positively high based on serviceability and comfort criteria. The high correlation coefficients indicate that level of 
importance of functional building performance criteria based on the POE has a strong positive relationship with the need of POE framework guideline in a public teaching hospital.

\section{b) Region B - Low correlations}

The correlation coefficient between functional building performance and the importance of POE Guideline are low based on aesthetics, social, culture, functionality, operative and maintenance (O\&M) circulation and psychology criteria. The low correlation coefficients show that level of importance of technical building performance criteria based on the POE has a low relationship with the need of POE framework guideline in a public teaching hospital. Despite having low correlation, it does not constitute negative correlation. This indicates the low correlation is the difference in perception between the building occupants due to different perception and expectation on criteria stipulated in questionnaires which are influenced by their background, working experience, knowledge, and technical skills.

These findings from the level of building performance and the importance of POE guideline determines the proposed guidelines which are needed to evaluate the performance of public teaching hospital in Malaysia in respective to functional and technical performance. The proposed guideline is shown in Figure 4.

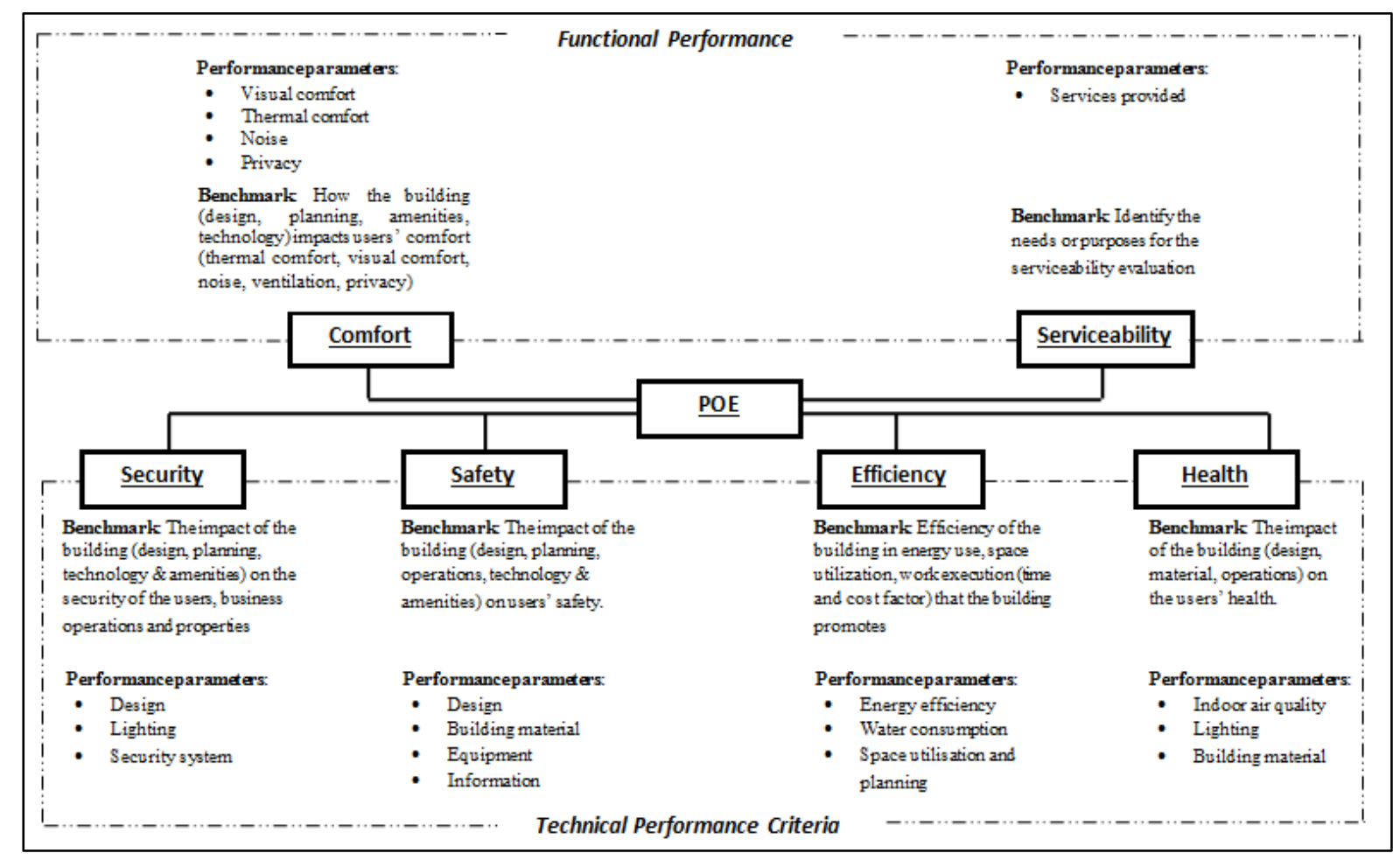

Figure 4: Proposed Framework of guideline on building performance in areas of functional and technical performance

\section{Finding and Conclusion}

This research involved correlation analysis of the results obtained. The findings show that there is a strong significant relationship among the building performance criteria and the importance of POE guidelines in functional 
and technical performance criteria. POE guidelines enable to address the problem and issues and enhance the satisfaction level of the public teaching health care and hospital organisation. The results gained from the study firstly can assist in portraying the general review of current state of facilities performance level on public health care teaching hospital building. Secondly, it enabled to comprehend the future betterment in fulfilling the user's demand and satisfaction. Identifying user's satisfaction will enable the facilities management and relevant ministries in identifying the weaknesses and improve the provided healthcare services. The results gained can assist in providing relevant databases in achieving an appropriate level of building performance criteria in the public teaching hospital building. Thus, the study fulfilled the research hypotheses; (i) conducive working environment would demonstrate more productive working performance and increase productivity; (ii) functional and technical performance factors of POE determine the user satisfaction in highly dynamic hospital building environment; and (iii) the established POE guidelines will address the problem and issues and enhance the satisfaction level of public teaching hospital organization

Higher user satisfaction and better service utilization in health care public teaching hospital building there is a need for more comprehensive documentation in the of the context of knowledge at preliminary planning and implementation, design expectations and how design decisions are made. The lack of detailed information will limit the designer evaluation's ability to understand the user's requirements, expectation, and satisfaction entirely. This will have the negative impacts in the design of built environment.

\section{References}

Atkin, B. and Brooks, A. (2009), Total Facilities Management, Wiley-Blackwell, Oxford.

Barrett, P. \& Baldry, D. (2003) Facilities Management: Towards Best Practice, UK, Blackwell Publishing.

Carr, R. F. (2011). Hospital. Retrieved May 7, 2012, from http://www.wbdg.org/design/hospital.php\#mjr

Chanter, B. and Swallow, P. (2007), Building Maintenance Management, Blackwell Publishing, Oxford

Fauzi, M. (2012). "Malaysia needs more teaching hospitals." The International Medical Journal Malaysia Vol.11 No.(2).

Gonza'Lez, M. E., Quesada, G., Mack, R. \& Urrutia, I. (2005) Building an Activity-Based Costing Hospital Model Using Quality Function Deployment and Benchmarking. Benchmarking: An International Journal, 12 310-329.

Hashim AE, Hasnizan A, Hasim MS, Samikon AS (2015), Health Care Building Assessment through Post Occupancy Audit, Asia Pacific International Conference on Environment-Behaviour Studies, AicE-Bs2015, 30 August- 04 September 2015, Barcelona, Spain, Procedia - Social and Behavioral Sciences.

Hafizi. Z., K. A., S. A., K. A., \& Z. F. (2010). Pengurusan Fasiliti Dalam Penyelenggaraan Bangunan: Amalan Kualiti, Keselamatan dan Kesihatan. Journal of Techno-Social, 23-36.

Kamaruzzaman, S. N., \& Ahmad Zawawi, E. M. (2010). Development of facilities management in Malaysia. Journal of Facilities Management, 8 , 75-81.

Kontodimopoulos, N., Nanos, P., \& Niakas D. (2006). Balancing efficiency of health services and equity of access in remote areas in Greece. Health Policy, 76, 49-57.

Kursunluoglu, E. (2011). Customer service effects on customer satisfaction and customer loyalty: A field research in shopping centers in Izmir City- Turkey. International Journal of Business and Social Sciences, 2, 52-59.

Lepkova, N., \& Žūkaitè-Jefimovienè, G. (2012). Study on customer satisfaction with facilities management services in Lithuania. Slovak Journal of Civil Engineering, 1-16.

Lewis, B. T. (2000) Facility Manager's Portable Handbook New York, USA, McGraw-Hill. 
Mohd Noor, M. N., \& Pitt, M. (2010). Defining facilities management (FM) in the Malaysian Perspectives. ERES Conference. Milano. Retrieved from http://www.propertyfinance.it/sitoeres/contents/papers/id2.pdf

Natasha, K. (2008). "Performance Analysis of Government and Public Building via Post Occupancy Evaluation."Asian Social Science, Vol, 4. No.9. September 2008

OSHA (2012), "Healthcare facilities", United States Department of Labors, Occupational Safety and Health Administration (OSHA), available at www.osha.gov/SLTC/healthcarefacilities/ (accessed 1 February 2012).

Payne, T. (2000) Facilities Management: A Strategy for Success, Oxford, UK, Chandos Publishing (Oxford) Limited.

Shohet, I.M., and Lavy, S. (2004), "Healthcare facilities management: state of the art review", Facilities, Vol. 22, pp. 210-220.

Wauters, B. (2005), "The added value of facilities management: benchmarking work processes", Facilities, Vol. 23 Nos 3/4, pp. 142-51

Friesen, S., L. Trojan, et al. (2008). "Relating Health Care Environment Design to Health Quality Outcomes: Post Occupancy Evaluation of The Ward of the 21st Century (Final Report)." 